\title{
LACTOSE HYDROLYSIS AND ORGANIC ACIDS PRODUCTION IN YOGURT PREPARED WITH DIFFERENT ONSET TEMPERATURES OF ENZYMATIC ACTION AND FERMENTATION
}

\section{HIDRÓLISE DA LACTOSE E PRODUÇÃO DE ÁCIDOS ORGÂNICOS EM IOGURTES ELABORADOS COM DIFERENTES TEMPERATURAS DE INICIO DE AÇÃO ENZIMÁTICA E FERMENTAÇÃO}

\author{
Raphael Ferreira Barros ${ }^{1 *}$ ORCID - http://orcid.org/0000-0002-3605-3716 \\ Camila Sampaio Cutrim ${ }^{1}$ ORCID - http://orcid.org/0000-0002-7109-760X \\ Marion Pereira da Costa ${ }^{1}$ ORCID - http://orcid.org/0000-0002-3003-6763 \\ Carlos Adam Conte Junior ${ }^{1}$ ORCID - http://orcid.org/0000-0001-6133-5080 \\ Marco Antonio Sloboda Cortez ${ }^{1}$ ORCID - http://orcid.org/0000-0003-0984-2338 \\ 1 Universidade Federal Fluminense, Niterói, RJ, Brazil \\ *Corresponding author - raphaelfbarros@veterinario.med.br
}

\begin{abstract}
The aim of this study was to evaluate lactose hydrolysis between two different initial temperatures of enzymatic and fermentation action to improve the fermentation period by checking the components formed and hydrolysis levels of lactose by HPLC. $\mathrm{pH}$ and titratable acidity analysis between treatments - higher initial temperature (HIT), $42{ }^{\circ} \mathrm{C}$, and lower initial temperature (LIT), $30{ }^{\circ} \mathrm{C}$ - were different $(\mathrm{P}<0.05)$ during the fermentation process. HIT obtained lower $\mathrm{pH}$ and higher titratable acidity values as $4.6 \pm 0.04$ and $0.73 \pm 0.01 \mathrm{~g}$ lactic acid. $100 \mathrm{~mL}^{-1}$, respectively, against $4.82 \pm 0.01$ and $0.64 \pm 0.01 \mathrm{~g}$ lactic acid.100 $\mathrm{mL}^{-1}$ from LIT. Lactose content was different $(\mathrm{P}<0.05)$ between treatments while fermenting; however, at the end of the fermentation, it reached $4.565 \pm 0.34 \mathrm{mg} . \mathrm{mL}^{-}$ ${ }^{1}$ and $4.398 \pm 0.18 \mathrm{mg} \cdot \mathrm{mL}^{-1}$ for LIT and HIT $(\mathrm{P}>0,05)$, respectively. Glucose and galactose remained buoyant during the fermentation period, which indicates its production and consumption at the same time by the lactic acid bacteria involved. The lactic acid concentration in LIT was higher $(\mathrm{P}<0.05)$ $\left(18.64 \pm 0.62 \mathrm{mg} \cdot \mathrm{mL}^{-1}\right)$ than in HIT $\left(17.56 \pm 0.53 \mathrm{mg} \cdot \mathrm{mL}^{-1}\right)$ although citric and acetic acids content decreased throughout the process. In conclusion, the lactase enzyme contributed to reduce the lactose content without affecting the fermentation process. In addition, both treatments obtained lower values of lactose, which is sufficient for the consumption by those who have lactose malabsorption.
\end{abstract}

Keywords: $\beta$-galactosidase; fermented milk; functional food; HPLC.

\section{Resumo}

O objetivo deste estudo foi avaliar a hidrólise da lactose em relação a duas diferentes temperaturas iniciais de ação enzimática e fermentação, a fim de melhorar o período de fermentação, verificando a formação de componentes e o nível de hidrolise por CLAE (HPLC). Os resultados das análises de $\mathrm{pH}$ e acidez titulável entre os tratamentos com maior temperatura inicial (HIT), $42{ }^{\circ} \mathrm{C}$, e menor temperatura inicial (LIT), $30^{\circ} \mathrm{C}$, foram diferentes $(\mathrm{P}<0,05)$ durante a fermentação. HIT obteve 
menores valores de $\mathrm{pH}$ e maiores valores de acidez titulável como 4,6 $\pm 0,04$ e $0,73 \pm 0,01 \mathrm{~g}$ acido láctico. $100 \mathrm{~mL}^{-1}$, respectivamente, contra 4,82 $\pm 0,01$ e $0,64 \pm 0,01 \mathrm{~g}$ acido láctico. $100 \mathrm{~mL}^{-1}$ de LIT. O teor de lactose difereriu $(\mathrm{P}<0,05)$ entre os tratamentos durante a fermentação; entretanto, no final do processo alcançaram 4,40 $\pm 0,14 \mathrm{mg} \cdot \mathrm{mL}^{-1}$ e $4,32 \pm 0,14 \mathrm{mg} \cdot \mathrm{mL}^{-1}$ para LIT e HIT $(\mathrm{P}>0,05)$, respectivamente. Teores de glicose e galactose mantiveram-se dinâmicos. A concentração de ácido láctico em LIT $(\mathrm{P}<0,05)$ foi maior $\left(18,64 \pm 0,62 \mathrm{mg} \cdot \mathrm{mL}^{-1}\right)$ que em HIT $(17,56 \pm 0,53 \mathrm{mg} \cdot \mathrm{mL}-1)$, embora o teor dos ácidos cítrico e acético tenha diminuído durante o processo. Assim, pode-se concluir que a enzima lactase contribuiu para reduzir o teor de lactose, sem influenciar o processo de fermentação. Além disso, ambos os tratamentos obtiveram valores mais baixos de lactose, o que é suficiente para o consumo por pessoas com intolerância a lactose.

Palavras-chave: $\beta$-galactosidase; alimento funcional; CLAE; leite fermentado; HPLC.

Received on October $4^{\text {th }}, 2016$.

Accepted on July $11^{\text {th }}, 2018$.

\section{Introduction}

Milk is considered a complete food: source of protein $(3.2 \mathrm{w} / \mathrm{w})$; carbohydrates, particularly lactose, $(4.7 \% \mathrm{w} / \mathrm{w})$, fat $(3.6 \% \mathrm{w} / \mathrm{w})$; minerals $(0.6 \mathrm{w} / \mathrm{w})$; and vitamins. Due to the essential nutrients and the high digestibility (bioavailability) of nutrients, milk and dairy products are considered highly nutritious food ${ }^{(1)}$. Lactose is the main carbohydrate in milk and is formed by one molecule of $\alpha$-Dglucose and $\beta$-D-galactose. In cow's milk, lactose concentration is around $4.8 \%$, which means 50 to $52 \%$ of total solids ${ }^{(2-3)}$. However, this lactose percentage can be detrimental to subjects with impaired or completely absent intestinal lactase activity (lactose malabsorption) $)^{(4)}$.

Lactose malabsorption, also known as lactose non-persistent, is due to poor digestion of this carbohydrate $^{(5)}$, causing gastrointestinal symptoms (lactose intolerance) $)^{(4)}$. Researchers have shown that more than $65 \%$ of the world's population - mostly adults - has a certain level of this disorder. Raithel $^{(6)}$ reported that lactose malabsorption has two different sources: a primary deficiency that includes physiological lactase reduction and autosomal recessive familial lactase deficiency; and a secondary deficiency featuring inflammatory intestinal diseases. Therefore, various technologies are employed for the development of reduced-lactose products, such as milk fermentation and enzymatic hydrolysis.

According to Codex Standards for Fermented Milk(7), yogurt is a fermented milk product by homofermentative acid lactic bacteria. In fermentation process, milk lactose is fermented by specific acid lactic cultures as Streptococcus thermophilus and Lactobacillus delbrueckii subsp. bulgaricus culminated mainly lactic acid production at the end of the metabolism chain ${ }^{(8-9)}$. Although there is a certain degree of lactose consumption by yogurt starter culture, a considerable amount of lactose remains intact in yogurt ${ }^{(3)}$.

Yogurt presents about 30\% less lactose than milk; however, it is still considered relatively high for some lactose malabsorption levels ${ }^{(10)}$. Only the milk fermentation process may not be not sufficient for people who have some level of lactose intolerance; therefore, one of the solutions for such cases is to elaborate a dairy product with reduced lactose or even lactose free, as the ones obtained with 
fermented milk added of $\beta$-galactosidase enzyme. Enzyme use in the manufacture of low-lactose dairy products is nowadays an usual practice ${ }^{(11)}$.

For these reasons, the hydrolysis conditions of milk lactose by the $\beta$-galactosidase enzyme action and the fermentation conditions by S. thermophilus and L. delbrueckii subsp. bulgaricus were compared between two treatments with different initial temperatures: low initial temperature $\left(25^{\circ} \mathrm{C}\right)$ and high initial temperature $\left(40^{\circ} \mathrm{C}\right)$. Therefore, the aim of this study was to evaluate lactose hydrolysis between two different initial temperatures of enzymatic and fermentation action. Components formation and hydrolysis levels of lactose were also checked, as well as whether the process obtained a low lactose concentration as required by humans with lactose malabsorption.

\section{Materials and Methods}

Commercial cow's whole UHT milk (Ninho ${ }^{\circledR}$, Nestle, São Paulo, Brazil), was used to elaborate the fermented milk. The milk was acquired in the retail market, transported and stored at room temperature. A whole milk sample was analyzed to indicate its physicochemical quality, determinate titratable acidity (Official Method 947.05), and $\mathrm{pH}$ (Official Method 973.41) ${ }^{(12)}$. The $\mathrm{pH}$ was determined by inserting a pH probe into milk ( $\mathrm{pH}$ meter PG1800, CapLab, São Paulo, Brazil) after calibrating it with fresh $\mathrm{pH} 4.0$ and 7.0 standard buffers.

To produce the yogurt, the dosage of $50 \mathrm{U}$ of thermophilic lactic acid culture (Streptococcus thermophilus and Lactobacillus delbrueckii subsp. bulgaricus strains YF L-812 CHR HANSEN ${ }^{\circledR}$ ) to $500 \mathrm{~L}$ of milk was used, as suggested by the supplier, aiming at a cellular count of $10^{11} \mathrm{CFU}_{\mathrm{Jg}}{ }^{-1}$ of product

The $\beta$-galactosidase enzyme used in this research to hydrolyze the lactose was Maxilact Lx 5000 (DSM Food Specialties, Delft, Netherlands), which is a refined lactase formulation derived from dairy yeast Kluyveromyces lactis. The dosage used was $0.45 \mathrm{~mL}$ of enzyme per liter of milk, as suggested by the supplier. The enzyme was added into milk and stirred at the start of fermentation in both treatments. The lactose hydrolysis and fermentation process were performed at an oven at $41 \pm 1{ }^{\circ} \mathrm{C}$ during fermentation time.

Yogurt was made by applying the improved traditional method (Figure 1) adapted to laboratory scale $^{(3)}$. It was prepared with whole milk, into two separated groups, using $3 \mathrm{~L}$ for each treatment. The first group, Low Initial Temperature (LIT), was prepared with milk at the temperature of $30{ }^{\circ} \mathrm{C}$ and the second one, High Initial Temperature (HIT), was prepared with milk at the temperature of $42{ }^{\circ} \mathrm{C}$. In both groups a single-stage process took place with the simultaneous addition of $\beta$ galactosidase enzyme and lactic acid culture, using the dosages recommended by the respective manufacturers (as reported above). The fermentation was performed in an oven at $42{ }^{\circ} \mathrm{C}$ for 5 hours (300 minutes); thus, after the first hour, both temperatures were the same. The process was interrupted when the $\mathrm{pH}$ reached $4.7 \pm 0.1$. After that, the yogurt was cooled immediately in a refrigerator at $4{ }^{\circ} \mathrm{C}$. 


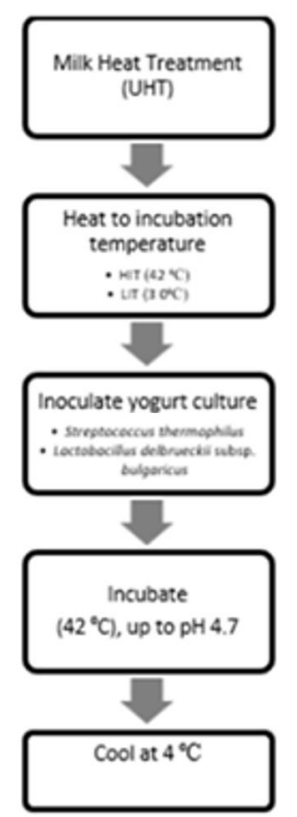

Figure 1. Scheme illustrating a method for yogurt production.

During fermentation, the yogurt was analyzed every each hour to determinate $\mathrm{pH}$ and titratable acidity ${ }^{(12)}$. In addition, the yogurt was also analyzed to determinate carbohydrates and organics acids, which was extracted and carried out as following described.

The carbohydrates and organics acids extraction was carried out using a modification of the method described by González de Llano et al. ${ }^{(13)}$, performed in triplicate. Five milliliters of $45 \mathrm{mMol} \mathrm{H}_{2} \mathrm{SO}_{4}$ were added onto $1 \mathrm{~mL}$ of each sample and homogenized by vortexing for one minute. After that, all samples remained under agitation for one hour in a shaker table (TS - 2000 A VDRL shaker, Biomixer $^{\circledR}$ ) and then they were centrifugated at $5500 \mathrm{~g}$ for 30 minutes at $4{ }^{\circ} \mathrm{C}$. Finally, the supernatant was filtered through Whatman no. 1 filter paper (Sigma-Aldrich, St. Louis, MO, USA).

Filtered samples were injected $(20 \mu \mathrm{L})$ in triplicate into an HPLC system consisted of a LC/20 AT pump integrated with CBM-20A and equipped with SPD-M20A diode array and refractive index RID-10A detectors (Shimadzu Corp., Tokyo, Japan). Carbohydrates and lactic acid separations were performed with an HPX-87H 300 x $7.8 \mathrm{~mm}$ Aminex cation-exchange column (Bio-Rad, Hercules, CA, USA), maintained at $60{ }^{\circ} \mathrm{C}$. The mobile phase used was $3 \mathrm{mM} \mathrm{H}_{2} \mathrm{SO}_{4}$ at isocratic flow rate at 0.5 $\mathrm{mL} \cdot \mathrm{min}^{-1}$. Chromatograms from HPLC and compound quantification were obtained using the LC Solution software (Shimadzu Corp., Tokyo, Japan). Calibration curves were made from standard solutions prepared in Milli-Q water (Millipore, Billerica, MA, USA). The interest peaks were identified by comparing retention times of the standards with the samples. The concentration of each samples components was determined from the area of individual peaks. Carbohydrates identification was performed by refractive index detector while lactic acid by using a diode array detector model monitoring the absorbance at $210 \mathrm{~nm}$.

One-way ANOVA with repeated measures of analytical methods was used to identify differences between $\mathrm{pH}$ values, titratable values, organic acids, and carbohydrates content over the yoghurt fermentation, as well as Tukey's test. Statistical significance was set at a 0.05 level of confidence. 
All analyses were performed using commercially available statistical package XLSTAT 2013.2.03 (Addinsoft, Paris, France).

\section{Results}

Milk physicochemical analyses results are presented in Table 1. Regarding hydrolysis and fermentation processes, the $\mathrm{pH}$ reached at the end of fermentation $(4.82 \pm 0.01$ for LIT and $4.6 \pm 0.04$ for HIT) was considered a $\mathrm{P}<0.05$ among the groups (Table 2). Moreover, the titratable acidity presented a similar result with HIT $\left(0.73 \mathrm{~g}\right.$ lactic acid. $\left.\mathrm{mL}^{-1}\right)$, higher $(\mathrm{P}<0.05)$ than LIT $(0.64 \mathrm{~g}$ lactic acid. $\mathrm{mL}^{-1}$ ), as seen in Table 3 .

Lactose concentration started at $56.29 \pm 1.009 \mathrm{mg} \cdot \mathrm{mL}^{-1}$. On the first four hours, HIT kept the lactose content $\mathrm{P}<0.05$ lower than LIT. Nevertheless, at the end of 300 minutes, the concentrations reached were $4.565 \pm 0.34 \mathrm{mg} \cdot \mathrm{mL}^{-1}$ and $4.398 \pm 0.18 \mathrm{mg} \cdot \mathrm{mL}^{-1}$ of lactose for LIT and HIT (Table 4), respectively. Hence, with simultaneous fermentation process and lactose enzymatic hydrolysis, this compound decreased in both treatments at the end of fermentation $(\mathrm{P}>0.05)$.

In contrast, glucose and galactose concentration started at a very low value $\left(0.16 \pm 0.007 \mathrm{mg} \cdot \mathrm{mL}^{-1}\right.$ and $0.89 \pm 0.044 \mathrm{mg} . \mathrm{mL}^{-1}$, respectively) and increased during the first hour. Then, these compounds decreased slowly and slightly in both treatments. At the end of the process, its glucose and galactose concentrations were $\mathrm{P}<0.05$. LIT ended the process with glucose and galactose concentration equal to $26.010 \pm 1.13 \mathrm{mg} \cdot \mathrm{mL}^{-1}$ and $21.72 \pm 0.75 \mathrm{mg} \cdot \mathrm{mL}^{-1}$, respectively. Likewise, HIT obtained concentrations of $21.72 \pm 0.75 \mathrm{mg} \cdot \mathrm{mL}^{-1}$ of glucose and $14.74 \pm 0.25 \mathrm{mg} \cdot \mathrm{mL}^{-1}$ of galactose.

Table 1. Characterization of UHT milk samples regarding $\mathrm{pH}$, titratable acidity, carbohydrates, and organic acids

\begin{tabular}{|c|c|c|c|}
\hline \multicolumn{2}{|c|}{ Analysis } & \multirow{2}{*}{$\frac{\text { Unit }}{\left(\mathrm{mg} \cdot \mathrm{mL}^{-1}\right)}$} & \multirow{2}{*}{$\begin{array}{c}\text { Results } \\
56.29 \pm 1.009\end{array}$} \\
\hline & Lactose & & \\
\hline \multirow{3}{*}{$\begin{array}{l}\text { Carbohydrates } \\
\text { (HPLC) }\end{array}$} & Glucose & $\left(\mathrm{mg} \cdot \mathrm{mL}^{-1}\right)$ & $0.16 \pm 0.007$ \\
\hline & Galactose & $\left(\mathrm{mg} \cdot \mathrm{mL}^{-1}\right)$ & $0.89 \pm 0.044$ \\
\hline & Lactic acid & $\left(\mathrm{mg} \cdot \mathrm{mL}^{-1}\right)$ & $0.15 \pm 0.158$ \\
\hline \multirow[t]{2}{*}{ Organic acids (HPLC) } & Acetic acid & $\left(\mathrm{mg} \cdot \mathrm{mL}^{-1}\right)$ & $13.52 \pm 2.958$ \\
\hline & Citric acid & $\left(\mathrm{mg} \cdot \mathrm{mL}^{-1}\right)$ & $14.24 \pm 0.757$ \\
\hline \multicolumn{2}{|c|}{ pH } & - & 6.58 \\
\hline \multicolumn{2}{|c|}{ Titratable acidity } & (g lactic acid $\left..100 \mathrm{~mL}^{-1}\right)$ & 0.16 \\
\hline
\end{tabular}


Table 2. $\mathrm{pH}$ determination values during the whole five hours (300 minutes) of milk fermentation process

\begin{tabular}{|c|c|c|c|c|c|c|}
\hline \multirow{2}{*}{ Group } & \multicolumn{6}{|c|}{ Fermentation time (min) } \\
\hline & 0 & 60 & 120 & 180 & 240 & 300 \\
\hline LIT & $6.54 \pm 0.02^{\mathrm{Aa}}$ & $6.34 \pm 0.01^{A b}$ & $6.13 \pm 0.01^{\mathrm{AC}}$ & $5.38 \pm 0.01^{\mathrm{Ad}}$ & $4.96 \pm 0.03^{\mathrm{Ag}}$ & $4.82 \pm 0.01^{A f}$ \\
\hline HIT & $6.52 \pm 0.01^{\mathrm{Aa}}$ & $5.95 \pm 0.02^{\mathrm{Bb}}$ & $5.36 \pm 0.01^{\mathrm{Be}}$ & $4.97 \pm 0.02^{\mathrm{Bd}}$ & $4.69 \pm 0.02^{\mathrm{Be}}$ & $4.60 \pm 0.04^{\mathrm{Bf}}$ \\
\hline
\end{tabular}

Table 3. Titratable acidity values measured during the whole five hours (300 minutes) of milk fermentation process

\begin{tabular}{c|cccccc}
\hline \multirow{2}{*}{ Group } & \multicolumn{7}{c}{ Fermentation time (minutes) } \\
& $\mathbf{0}$ & $\mathbf{6 0}$ & $\mathbf{1 2 0}$ & $\mathbf{1 8 0}$ & $\mathbf{2 4 0}$ & $\mathbf{3 0 0}$ \\
\hline LIT & $0.16^{\mathrm{Aa}}$ & $0.20^{\mathrm{Bb}}$ & $0.29 \pm 0.01^{\mathrm{Be}}$ & $0.45 \pm 0.01^{\mathrm{Bd}}$ & $0.55 \pm 0.01^{\mathrm{Be}}$ & $0.64 \pm 0.01^{\mathrm{Bf}}$ \\
HIT & $0.16^{\mathrm{Aa}}$ & $0.27 \pm 0.01^{\mathrm{Ab}}$ & $0.47 \pm 0.01^{\mathrm{Ae}}$ & $0.60 \pm 0.01^{\mathrm{Ad}}$ & $0.67 \pm 0.01^{\mathrm{Ae}}$ & $0.73 \pm 0.01^{\mathrm{Af}}$ \\
\hline
\end{tabular}

A.D Cajital letters in the columns indicate significant differences among the different treatments, $\mathrm{P}<0.05$.

3-d Lowercase letters in rows indicate significant differences among different times in the treatment, $\mathrm{p}<0.05$.

The lactic acid concentration at the beginning of fermentation was $0.152 \pm 0.015 \mathrm{mg} \cdot \mathrm{mL}^{-1}$ and after 300 minutes of procedure, the lactic acid concentration reached $18.644 \pm 0.62 \mathrm{mg}^{-\mathrm{mL}^{-1}}$ in LIT and $17.557 \pm 0.53 \mathrm{mg} . \mathrm{mL}^{-1}$ in HIT. From the beginning of procedure to the end, there was a significant difference between the treatments. However, either treatments have had an increase in lactic acid content. Regarding the acetic and citric acids content during fermentation, its amount remained constant around $13.52 \pm 2.958 \mathrm{mg} \cdot \mathrm{mL}^{-1}$ and $14.24 \pm 0.757 \mathrm{mg} \cdot \mathrm{mL}^{-1}$, respectively. 


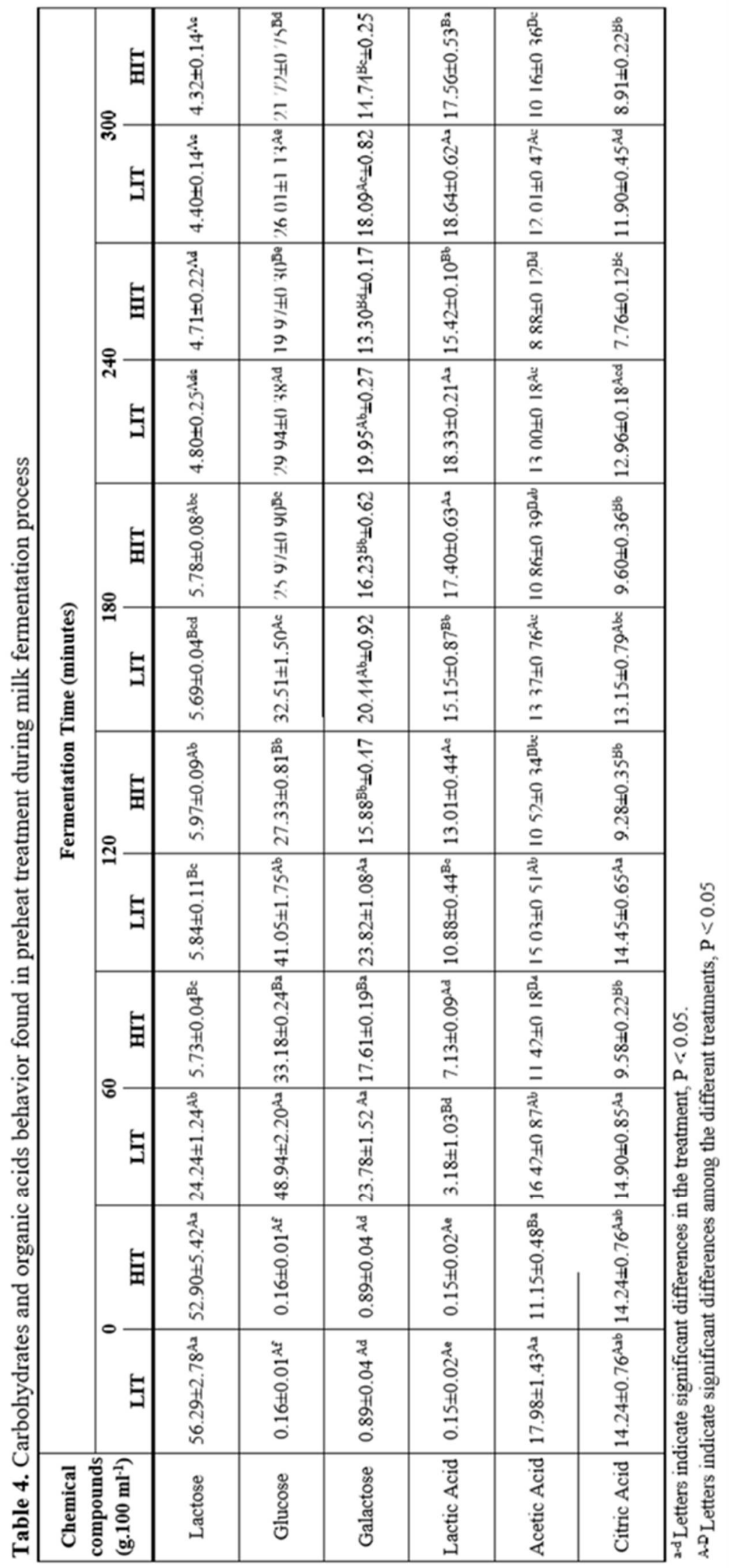




\section{Discussion}

Raw milk was analyzed and its result indicated good quality as expected. During fermentation, the initial $\mathrm{pH}$ of milk decreased, while titratable acidity increased in both treatments (LIT and HIT). These decrease and increase were evidently due the lactic acid production by lactose fermentation, as a result of microorganism metabolism. One of the lactic acid bacteria features are their capacity to ferment the mainly carbohydrate in milk and dairy products producing lactic acid as end product. The organic acids produced contribute not only to the flavor and aroma of fermented dairy products but also to their preservation.

Although a lower level of lactose results in a higher level of glucose and galactose, as it is seen in traditional yogurts ${ }^{(20)}$, the addition of the enzyme showed a significantly lower lactose content, however, galactose and glucose values were not very high. The lactose hydrolysis by enzymatic via is one of the most evaluated strategies to achieve yogurt with low lactose content ${ }^{(14)}$. The addition of $\beta$-galactosidase changes the carbohydrate pattern, which may affect the sugar consumption by the starter culture. Consequently, this fact could interfere with the production of derived compounds as well as the physicochemical and sensory characteristics of the products ${ }^{(11,15)}$. Furthermore, lactic acid culture cleaved the lactose into its monosaccharides and organic acids component, being lactic acid the predominant one, as previously reported ${ }^{(3,16-19)}$.

According to Mora et al. ${ }^{(21)}$ and De Vin et al. ${ }^{(22)}$, most of the lactic acid bacteria are efficiently capable of using the glucose portion of lactose and releasing galactose into the medium. S. thermophilus is able to metabolize lactose. In addition, the majority of this strains are galactose negative (Gal-). However, some strains are galactose positive $(\mathrm{Gal}+)$, i.e., they are able to metabolize galactose ${ }^{(9)}$. This fact may explain the galactose behavior after 60 minutes fermentation.

In preheat treatment, the greater hydrolysis of lactose, observed at the beginning of fermentation, as compared to LIT treatment, is related to the increase in $\beta$-galactosidase activity. Whilst $\beta$ galactosidases are stable at temperatures between 20 and $37^{\circ} \mathrm{C}$, these enzymes are found to have optimum temperatures around 40 and $50{ }^{\circ} \mathrm{C}$. In this condition, they retained $90-100 \%$ of their activity ${ }^{(23)}$. As reported by Chandan and $\mathrm{O}^{\prime} \mathrm{Rell}^{(24)}, 40-45^{\circ} \mathrm{C}$ is an optimum growth temperature for yogurt culture. It contributes to HIT quickly decreased $\mathrm{pH}$ and ripping. For the Maxilact ${ }^{\circledR}$ manufacturer description, the enzyme used to hydrolyze the lactose is a compound extracted from a milk yeast; therefore, the optimum conditions for their activity are similar to the natural milk $\mathrm{pH}(6.6)$ and temperature $\left(35-40{ }^{\circ} \mathrm{C}\right)$.

\section{Conclusion}

Our findings confirmed that both treatments obtained a final low lactose concentration although there was $\mathrm{P}>0.05$ between the different initial temperatures $\left(30\right.$ or $41^{\circ} \mathrm{C}$. Thus, the enzyme contributed to reduce lactose to a low-level providing for consumption by humans who have lactose malabsorption. The simultaneous enzymatic lactose hydrolysis and lactose-cleaving activity by yogurt cultures did not prevent the fermentation process, regardless of the initial temperature, including proper yogurt 
fermentation and maintaining the physical and chemical characteristics.

\section{Acknowledgments}

We express our thanks to the "Coordenação de Aperfeiçoamento de Pessoal de Nível Superior" (CAPES) and to the "Pró Reitoria de Pesquisa, Pós Graduação e Inovação" of Fluminense Federal University (PROPPI-UFF) for the financial support for this research, in addition to the Veterinary Medicine Graduate Program.

\section{References}

1. Park YW, Juárez M, Ramos M, Haenlein GFW. Physico-chemical characteristics of goat and sheep milk. Small Ruminant Research; 2007. 68:88-113.

2. Fox PF. Lactose: Chemistry and Properties. In: McSweeney PLH, Fox PF. Advanced Dairy chemistry: Lactose, Water, Salts and Minor Constituents. 3rd rev. Ireland: Springer; 2009 . p. 1-13.

3. Tamine AY, Robinson RK. Yoghurt: science and technology. 3rd rev. New York: CRC Press; 2007. 791 p.

4. Misselwitz B, Pohl D, Frühauf H, Fried Michael, Vavricka SR and Fox M. Lactose malabsorption and intolerance: pathogenesis, diagnosis and treatment. United Gastroenterology Journal. 2013; 1(3):151-159.

5. Vuorisalo T, Arjamaa O, Vasemägi A, Taavitsainen J, Tourunen A, Saloniemi I. Perspectives in Biology an High Lactose Tolerance in North Europeans: A Result of Migration, Not In Situ Milk Consumption. Perspectives in Biology and Medicine. 2012; 55 (2): 163-174.

6. Raithel M, Weidenhiller M, Hagel AFK, Hetterich U, Neurath MF, Konturek PC. The Malabsorption of Commonly Occurring Mono and Disaccharides. Deutsches Ärzteblatt International. 2013; 110(46): 775-82.

7. Codex (2003) Codex Alimentarius: Milk and Milk Products - Standard for Fermented Milks. Available in: http://www.codexalimentarius.org/standards/list-of-standards. Accessed 01 sep 2016

8. Adhikari K, Gruw IU, Mustapha A, Fernando LN. Changes in the Profile of Organic Acids in Plain Set and Stirred Yogurts During Manufacture and Refrigerated Storage. Journal of Food Quality. 2002; 25:435-451.

9. Anbukkarasi K, UmaMaheswari T, Hemalatha T, Nanda DK, Singh P, Singh R. Preparation of low galactose yogurt using cultures of Gal+ Streptococcus thermophilus in combination with Lactobacillus delbrueckii ssp. bulgaricus. Journal of Food Science and Technology. 2014; 51(9):2183-2189.

10. Schaafsma G. Lactose and lactase derivatives as bioactive ingredients in human nutrition. International Dairy Journal. 2008; 18:458-465.

11. Wolf IV, Vénica CI, Perotti M. Effect of reduction of lactose in yogurts by addition of b-galactosidase enzyme on volatile compound profile and quality parameters. Journal of Food Science and Technology. 2015; Doi:10.1111/ijfs. 12745 .

12. AOAC. Association Of Official Agricultural Chemists. Official methods of analysis. 19th rev. 
Gaithersburg, MD -USA: AOAC Intl. 2012.

13. González de Llano D; Rodriguez A; Cuesta P. Effect of lactic starter cultures on the organic acid composition of milk and cheese during ripening - Analysis by HPLC. Journal of Applied Microbiology. 1996; 80:570-576

14. Mlichova Z, Rosenberg M. Current trends of b-galactosidase application in food technology. Journal of Food and Nutrition Research. 2006; 45:47-54.

15. Vénica CI, Bergamini CV, Zalazar CA,Perotti MC. Effect of lactose hydrolysis during manufacture and storage of drinkable yogurt. Journal of Food \& Nutritional Disorders. 2013; $2: 5$

16. O'leary VS, Woychik JH. Utilization of lactose, glucose, and galactose by a mixed culture of Streptococcus thermophilus and Lactobacillus bulgaricus in milk treated with lactase enzyme. Applied and Environmental Microbiology. 1976; 32: 89-94

17. Dave RI, Shah NP. Viability of yoghurt and probiotic bacteria in yoghurts made from commercial starter cultures. International Dairy Journal. 1997; 7(1):31-41

18. Ordóñez JA., Rodriguez MIC, Álvarez LF, Sanz MLG, Minguillón FDGF, Parales LH, Cortecero MDS. Tecnologia de alimentos - Alimentos de Origem Animal v.2. Porto Alegre: Artmed; 2005. 280p.

19. Walstra P, Wouters JTM, Geurts TJ. Dairy Science and Technology. 2nd rev. London: CRC Press; 2014. $808 \mathrm{p}$.

20. Costa MP, Frasao BS, Lima BRCC, Rodrigues BL, Conte Junior CA. Simultaneous analysis of carbohydrates and organic acids by HPLC- DAD-RI for monitoring goat's milk yogurts fermentation. Talanta. 2016; 162-170.

21. Mora D, Fortina MG, Parini C, Ricci G, Gatti M, Giraffa G, Manachini PL. Genetic diversity and technological properties of Streptococcus thermophilus strains isolated from dairy products. Journal of Applied Microbiology. 2002; 93(2):278-287.

22. De Vin F, Radström P, Herman L, De Vuyst L. Molecular and biochemical analysis of the galactose phenotype of dairy Streptococcus thermophilus strains reveals four different fermentation profiles. Applied and Environmental Microbiology. 2005; 7:3659-3667.

23. Ustok FI, Tari C, Harsa S. Biochemical and thermal properties of $\beta$-galactosidase enzymes produced by artisanal yoghurt cultures. Food Chemistry. 2010; 119:1114-1120.

24. Chandan RC, O'Rell K. Yogurt: fruit preparations and fl avoring materials In: Chandan RC, Kilara A. Manufacturing Yogurt and Fermented Milks. 2nd rev. West Sussex: Wiley Blackwell; 2013. p. 193-215. 